\title{
SYNTHESIS AND ANTIOXIDANT ACTIVITY OF NOVEL PYRAZOLINE DERIVATIVES
}

\section{B.C. REVANASIDDAPPA*, M.VIJAY KUMAR, HEMANTH KUMAR}

Department of Pharmaceutical Chemistry, NGSM Institute of Pharmaceutical Sciences of Nitte -Deemed to be University, Paneer, Deralakatte, Mangalore-575 018, Karnataka, India

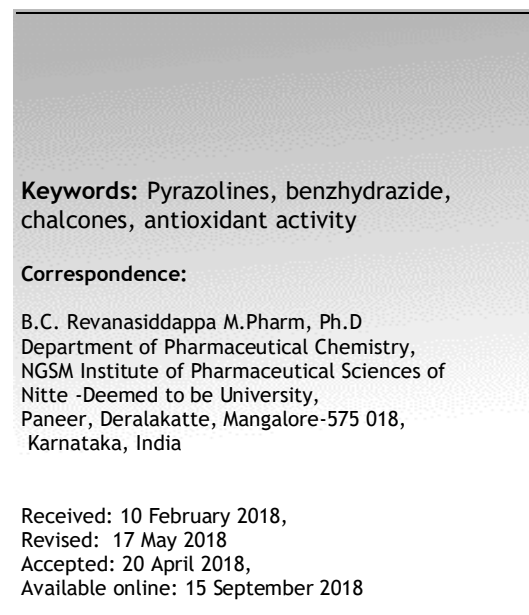

\begin{abstract}
Plan: A novel series of pyrazolines were synthesized through chalcones. The synthesized compounds were evaluated for various antioxidant activities.

Preface: Pyrazolines belongs to five membered nitrogen classes of compounds. Pyrazolines were reported with wide spread of chemotherapentic activities.

Methodology: A new series of Chalcones (2a-j) were prepared by reacting substituted aldehydes and ketones in alcohol medium in presence of $\mathrm{NaOH}$. The chalcones (2a-j) undergoes selective cyclization with benzhydrazide (1) in glacial acetic acid medium to yield the title compounds 1, 3, 5-trisubstituted Pyrazolines (3a-j). The new compounds were assigned on the basis of ${ }^{1} H-N M R$, IR and Mass spectral data. The newly synthesized compounds were screened for their In-Vitro antioxidant activity by DPPH, super oxide and nitric oxide methods.

Outcome: Some of the tested compounds $3 e, 3 g$, and $3 f$ showed moderate activity when compared to the standard drug ascorbic acid.
\end{abstract}

\section{INTRODUCTION}

Nitrogen containing heterocyclic compounds has been continuing to attract the researchers in the field of chemistry. The fascination towards the nitrogen containing heterocyclic compounds attributes due to their diversified biological activities. The dihydro derivative of Pyrazole is known as Pyrazoline. These are 5membered heterocyclic compounds and various methods have been worked out for their synthesis. The ring is quite stable and has inspired chemists to carryout various structural variations in the ring.. Pyrazolines are reported to possess analgesic ${ }^{1}$, anti-inflammatory ${ }^{2}$, antimicrobial ${ }^{3}$, antiamoebic ${ }^{4}$, antipyretic ${ }^{5}$ and antidepressant ${ }^{6}$ activities. The pyrazoline nucleus is the ubiquitous feature of various compounds possessing many pharmacological and physiological activities and therefore they are useful material in drug research. 
Chalcones are basically 1, 3-diaryl-2-propen-1-ones and are natural or synthetic compounds prepared by well known Claisen-Schmidt condensation reaction. The presence of reactive $\alpha, \beta$ - unsaturated keto group in chalcones is found to be responsible for their biological activity. Chalcones represent an essential group of natural as well as synthetic products and they are reported to possess wide range of activities such as antimalarial $^{7}$, antileshmanaial ${ }^{8}$, cytotoxic ${ }^{9}$, antitubercular ${ }^{10}$, anti-inflammatory ${ }^{11}$, antibacterial ${ }^{12}$ etc. Moreover, chalcones are useful synthons in the synthesis of a large number of bioactive molecules such as pyrazolines. These compounds found application in the synthesis of various heterocyclic compounds.

Based on the above pharmacological profile of both chalcones and pyrazolines, and as part of our continuous efforts in this area ${ }^{13-16}$, in the present work we have planned to synthesize a new series of pyrazolines from the key intermediate chalcones and their subsequent evaluation for antioxidant activities.

\section{MATERIALS AND METHODS}

Melting points were determined in open capillary tube and are uncorrected. All the chemicals were obtained of analytical grade purity. IR spectra were recorded by using Alpha Bruker IR spectrometer using a thin film on $\mathrm{KBr}$ pellet technique and frequencies are expressed in $\mathrm{cm}^{-1}{ }^{1} \mathrm{H}-\mathrm{NMR}$ spectra were recorded on Bruker Avance II 300 NMR spectrometer. All spectra were obtained in DMSO. All the chemical shift are expressed in $\delta$ ppm relative to TMS $(\delta=0)$ as internal standard. Mass spectra were recorded on Perkin Elmer Clarus 680 GC-MS spectrometer. TLC was used to monitor the progress of the reaction. TLC was done on precoated $0.2 \mathrm{~mm}$ Merck silica gel 60 plates.

\subsection{General procedure for synthesis of chalcones $(2 a-j)^{13}$}

A mixture of substituted aromatic aldehydes [0.01 mol] and substituted ketones [0.01 mol] in ethanol [20 ml] were stirred together for $24 \mathrm{hr}$, in presence of $40 \% \mathrm{NaOH}$ [5 ml]. The reaction mixture was poured into crushed ice and acidified with dilute $\mathrm{HCl}$. The precipitated compound obtained was filtered, washed with water and recrystallized from suitable solvents.

\subsection{Synthesis of substituted 1, 3, 5-trisubstituted Pyrazolines $(3 a-j)^{16}$}

Chalcones (2a-j) [0.01 mol] and benzhydrazide (1) [0.01mol] were dissolved in glacial acetic acid [20ml], and the reaction mixture is refluxed for about 10-18 hrs. The reaction mixture is cooled and poured into $100 \mathrm{ml}$ of ice cold water with constant stirring. The solid which is precipitated is filtered, washed with

cold water, dried and recrystallized by using alcohol. The physical data of pyrazolines (3a-j) is given in Table 1. 
Table 1: Physical data of Pyrazoline Derivatives (3a-j)

\begin{tabular}{cccccc}
\hline Comp. & $\mathrm{Ar}-\mathrm{CHO}$ & $\mathrm{Ar}^{\mathrm{l}}-\mathrm{COCH}$ & Molecular weight & M.P $\left({ }^{0} \mathrm{C}\right)$ & Yield $(\%)$ \\
\hline 3a & $4-\mathrm{Cl}$ & $4-\mathrm{Cl}$ & 395.28 & $105-07$ & 66 \\
$3 \mathrm{~b}$ & $4-\mathrm{Cl}$ & $4-\mathrm{OH}$ & 376.84 & $95-97$ & 54 \\
3c & $4-\mathrm{Cl}$ & $4-\mathrm{NO}_{2}$ & 405.83 & $116-18$ & 58 \\
3d & $4-\mathrm{Cl}$ & $4-\mathrm{CH}_{3}$ & 374.86 & $124-26$ & 62 \\
3e & $4-\mathrm{Br}$ & $4-\mathrm{Cl}$ & 439.73 & $137-39$ & 68 \\
3f & $4-\mathrm{Br}$ & $4-\mathrm{OH}$ & 421.29 & $112-14$ & 69 \\
$3 \mathrm{~g}$ & $4-\mathrm{Br}$ & $4-\mathrm{NO}_{2}$ & 449.04 & $154-56$ & 66 \\
$3 \mathrm{~h}$ & $4-\mathrm{Br}$ & $4-\mathrm{CH}_{3}$ & 419.31 & $177-79$ & 68 \\
$3 \mathrm{i}$ & $4-\mathrm{OH}$ & $4-\mathrm{CH}_{3}$ & 356.42 & $130-32$ & 63 \\
$3 \mathrm{j}$ & $4-\mathrm{OH}$ & $4-\mathrm{Br}$ & 421.29 & $143-45$ & 64 \\
\hline
\end{tabular}

3c: IR (KBr) v (cm-1): 1501(C=C), 1582(C=N), 1658(C=O), $3095(\mathrm{C}-\mathrm{H})$, 1H-NMR (300 MHz, DMSO-d $)$ : $\delta$ 7.28-7.32 (dd, $\left.1 \mathrm{H}, \mathrm{H}_{\mathrm{A}}\right), 7.37-7.39\left(\mathrm{dd}, 2 \mathrm{H}, \mathrm{H}_{\mathrm{B}}, \mathrm{H}_{\mathrm{X}}\right), 7.71-8.08(\mathrm{~m}, \mathrm{Ar}-\mathrm{H}, 13 \mathrm{H}) . \mathbf{M S}(\mathbf{m} / \mathbf{z}): 405\left(\mathrm{M}^{+}\right)$. 3i: IR $(\mathbf{K B r}) \boldsymbol{v}\left(\mathbf{c m}^{-1}\right): 1512(\mathrm{C}=\mathrm{C})$, 1588(C=N), 1699(C=O), 3097(C-H), $3353(\mathrm{OH}) .{ }^{1}$ H-NMR (300 MHz, DMSO-d $\left.)_{6}\right): \delta 2.08\left(\mathrm{~s}, \mathrm{CH}_{3}, 3 \mathrm{H}\right), 7.47-7.49\left(\mathrm{dd}, 3 \mathrm{H}, \mathrm{H}_{\mathrm{A}}\right.$, Hв, Hx), 7.63-8.10 (m, Ar-H, 13H), $\left.10.34(\mathrm{~s}, 1 \mathrm{H}, \mathrm{OH}) . \mathbf{M S}(\mathbf{m} / \mathbf{z}): 356\left(\mathbf{M}^{+}\right) \mathbf{3 j}: \mathbf{I R}(\mathbf{K B r}) \boldsymbol{v}\left(\mathbf{c m}^{-1}\right): 1512(\mathrm{C}=\mathrm{C}), 1589 \mathrm{C}=\mathrm{N}\right)$,

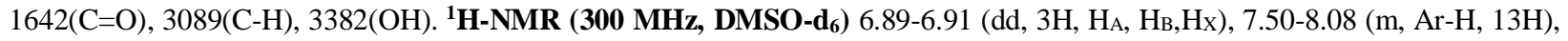
$10.41(\mathrm{~s}, 1 \mathrm{H}, \mathrm{OH}) . \mathbf{M S}(\mathbf{m} / \mathbf{z}): 421\left(\mathrm{M}^{+}\right)$.

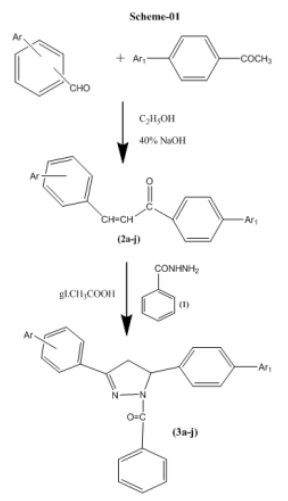

\subsection{Antioxidant Activity}

2.3.1. Superoxide anion scavenging activity ${ }^{17}$

About $1 \mathrm{ml}$ of nitro blue tetrazolium (NBT) solution $(156 \mu \mathrm{M}$ NBT in $100 \mathrm{mM}$ phosphate buffer, $\mathrm{pH}$ 7.4), $1 \mathrm{ml} \mathrm{NADH}$ solution $(468 \mu \mathrm{M}$ in $100 \mathrm{~m} \mathrm{M}$ phosphate buffer, $\mathrm{pH} 7.4)$ and $0.1 \mathrm{ml}$ of sample solution $(10-50 \mu \mathrm{g} / \mathrm{ml})$ in water is mixed. The reaction is started by adding $100 \mu \mathrm{l}$ of phenazinemethosulphate (PMS) solution $(60 \mu \mathrm{M}$ PMS in $100 \mathrm{~m}$ M phosphate buffer, $\mathrm{pH} 7.4)$ to the mixture. The reaction mixture is incubated at $25^{\circ} \mathrm{C}$ for 5 minutes, and the absorbance was recorded at $560 \mathrm{~nm}$ using ELISA plate reader and the results were calculated using the formula given in Eqn.1. Ascorbic acid was used as standard drug material. The results obtained by super oxide activity are given in Table 2 and Figure 1. The percentage scavenging activity was calculated using the following formula:

$$
\% \text { scavenging }=\frac{\text { Control }- \text { Test }}{\text { Control }} \times 100 \quad \ldots \ldots \ldots \ldots \text { Eqn .............. (1) }
$$


Table-2: Data of super oxide radical scavenging activity of Pyrazoline derivatives (3a-j)

\begin{tabular}{|c|c|c|c|c|c|c|c|c|c|c|c|}
\hline \multicolumn{12}{|c|}{ Percentage inhibition } \\
\hline Conc. & Std & $3 a$ & $3 b$ & $3 c$ & $3 d$ & $3 e$ & $3 f$ & $3 g$ & $3 h$ & $3 i$ & $3 j$ \\
\hline $10 \mu \mathrm{g} / \mathrm{ml}$ & 32.06 & 20.32 & 17.24 & 11.21 & 8.95 & 18.98 & 16.69 & 21.33 & 14.21 & 22.22 & 18.41 \\
\hline $20 \mu \mathrm{g} / \mathrm{ml}$ & 40.24 & 28.36 & 24.55 & 19.45 & 18.66 & 30.21 & 31.21 & 33.11 & 25.08 & 31.01 & 31.45 \\
\hline $30 \mu \mathrm{g} / \mathrm{ml}$ & 55.65 & 40.25 & 33.54 & 30.11 & 33.1 & 45.74 & 44.21 & 45.1 & 38.33 & 42.55 & 43.21 \\
\hline $40 \mu \mathrm{g} / \mathrm{ml}$ & 67.31 & 54.25 & 45.78 & 45.08 & 45.21 & 58.81 & 58.21 & 58.21 & 52.11 & 51.30 & 55.21 \\
\hline $50 \mu \mathrm{g} / \mathrm{ml}$ & 75.22 & 62.32 & 52.11 & 53.1 & 59.21 & 70.21 & 68.33 & 69.24 & 65.1 & 65.21 & 68.11 \\
\hline$I C_{50}$ & 16.39 & 28.10 & 36.88 & 36.64 & 33.36 & 23.98 & 24.81 & 23.81 & 28.57 & 27.10 & 25.46 \\
\hline
\end{tabular}

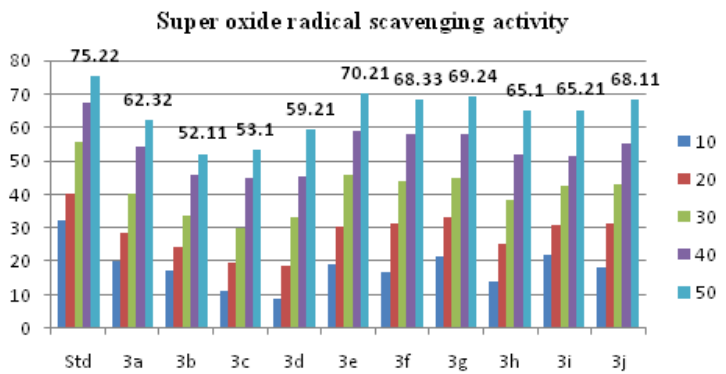

Fig-1: Data of super oxide radical scavenging activity

\subsubsection{DPPH free radical scavenging activity ${ }^{18}$}

The free radical scavenging activity of the title compounds was measured by using 2,2-diphenyl-1picrylhydrazyl (DPPH) method. $0.2 \mathrm{mM}$ solution of DPPH in methanol was prepared and $100 \mu 1$ of this solution was added to title compounds $(10-50 \mu \mathrm{g} / \mathrm{ml})$. After 30 minutes, absorbance was measured at $517 \mathrm{~nm}$ using ELISA plate reader. Ascorbic acid was used as standard drug material. The results by DPPH radical scavenging assay is given in Table 3 and Figure 2.

Table-3: Data of DPPH radical scavenging activity of Pyrazoline derivatives (3a-j)

\begin{tabular}{|c|c|c|c|c|c|c|c|c|c|c|c|}
\hline \multicolumn{12}{|c|}{ Percentage inhibition } \\
\hline Conc. & Std & $3 a$ & $3 b$ & $3 c$ & $3 d$ & $3 e$ & $3 f$ & $3 g$ & $3 h$ & $3 i$ & $3 j$ \\
\hline $10 \mu \mathrm{g} / \mathrm{ml}$ & 33.66 & 25.31 & 8.22 & 11.23 & 18.32 & 17.44 & 14.76 & 18.22 & 10.58 & 14.33 & 21.33 \\
\hline $20 \mu \mathrm{g} / \mathrm{ml}$ & 42.01 & 32.88 & 19.77 & 24.55 & 29.11 & 30.11 & 29.31 & 28.24 & 21.11 & 25.11 & 32.11 \\
\hline $30 \mu \mathrm{g} / \mathrm{ml}$ & 53.22 & 45.03 & 33.10 & 39.55 & 37.06 & 39.11 & 31.14 & 43.12 & 32.44 & 37.22 & 45.11 \\
\hline $40 \mu \mathrm{g} / \mathrm{ml}$ & 62.88 & 54.18 & 45.69 & 47.11 & 46.01 & 50.12 & 44.03 & 55.02 & 45.03 & 48.06 & 55.02 \\
\hline $50 \mu \mathrm{g} / \mathrm{ml}$ & 72.14 & 67.84 & 59.85 & 56.12 & 62.31 & 65.49 & 58.33 & 68.02 & 55.08 & 60.12 & 68.02 \\
\hline$I C_{50}$ & 17.16 & 24.66 & 32.91 & 32.72 & 30.91 & 28.22 & 34.22 & 25.92 & 35.19 & 31.38 & 24.89 \\
\hline
\end{tabular}

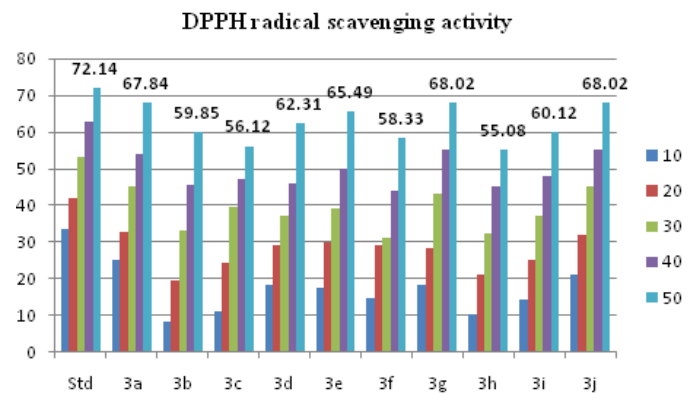

Fig-2: Data of DPPH radical scavenging activity 


\subsubsection{Nitric oxide radical scavenging activity ${ }^{19}$}

Sodium nitroprusside $(1 \mathrm{ml}$ of $10 \mathrm{mM})$ is mixed with $1 \mathrm{ml}$ of test compounds at different concentration $(10-50 \mu \mathrm{g} / \mathrm{ml})$ in phosphate buffer $\left(\mathrm{pH} \mathrm{7.4)}\right.$. The mixture is incubated at $25^{\circ} \mathrm{C}$ for $150 \mathrm{~min}$. $1 \mathrm{ml}$ of Griess's reagent (1\% sulphanilamide, $2 \%$ o-phosphoric acid and $0.1 \%$ naphthyl ethylene diamine dihydrochloride) is added to all the incubated solution. Absorbance is read at $546 \mathrm{~nm}$ using ELISA plate reader. Ascorbic acid was used as standard drug material. The results by nitric oxide radical scavenging assay are given in Table 4 and Figure 3.

Table-4: Data of nitric oxide radical scavenging activity of Pyrazoline derivatives (3a-j)

\begin{tabular}{|c|c|c|c|c|c|c|c|c|c|c|c|}
\hline \multicolumn{12}{|c|}{ Percentage inhibition } \\
\hline Conc. & Std & $3 a$ & $3 b$ & $3 c$ & $3 d$ & $3 e$ & $3 f$ & $3 g$ & $3 h$ & $3 i$ & $3 j$ \\
\hline $10 \mu \mathrm{g} / \mathrm{ml}$ & 24.29 & 20.11 & 18.66 & 17.01 & 17.22 & 22.02 & 14.11 & 17.22 & 20.88 & 24.33 & 22.01 \\
\hline $20 \mu \mathrm{g} / \mathrm{ml}$ & 38.12 & 31.02 & 28.33 & 28.09 & 33.18 & 35.11 & 26.11 & 28.46 & 31.02 & 32.11 & 32.02 \\
\hline $30 \mu \mathrm{g} / \mathrm{ml}$ & 55.18 & 43.55 & 40.11 & 40.12 & 46.11 & 46.11 & 34.88 & 35.06 & 43.44 & 43.08 & 44.08 \\
\hline $40 \mu \mathrm{g} / \mathrm{ml}$ & 67.97 & 55.26 & 52.08 & 52.18 & 58.22 & 58.07 & 44.05 & 41.02 & 55.08 & 55.66 & 57.69 \\
\hline $50 \mu \mathrm{g} / \mathrm{ml}$ & 80.21 & 62.88 & 63.09 & 66.28 & 74.11 & 70.22 & 57.01 & 55.08 & 63.09 & 63.08 & 68.02 \\
\hline$I C_{50}$ & 17.77 & 26.77 & 28.48 & 27.55 & 23.05 & 23.09 & 34.24 & 36.57 & 26.73 & 26.28 & 24.45 \\
\hline
\end{tabular}

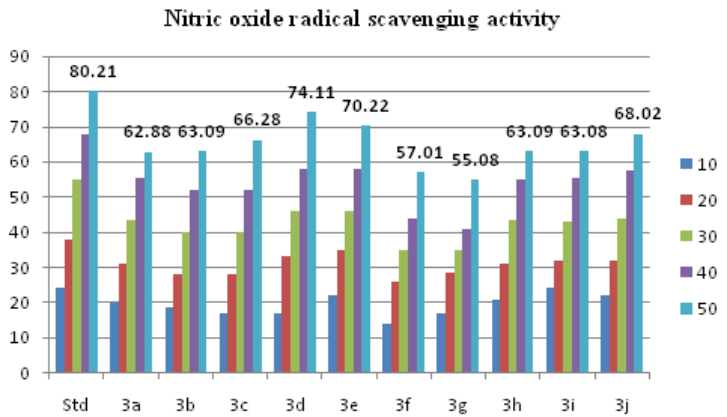

Fig-3: Data of nitric oxide radical scavenging activity

\section{RESULTS AND DISCUSSION}

\subsection{Chemistry}

The aim of the present study was to design and synthesize a new series of pyrazolines and to evaluate for various antioxidant activities. The key intermediate chalcones have been synthesized by Claisen-Schmidt condensation between appropriate aromatic aldehydes and ketones in presence of alcoholic basic medium. These chalcones undergoes selective cyclization with benzhydrazide in glacial acetic acid medium. Synthetic route leading to the formation of target compounds are summarized in Scheme-01. The physicochemical properties of pyrazoline derivatives are presented in table-1. 
The final structures of these compounds were proven on the basis of melting points and spectroscopic data. The ${ }^{1} \mathrm{H}-\mathrm{NMR}$ spectrum of compound 3c showed $\delta$ 7.28-7.32, $\delta$ 7.37-7.39 corresponding to three protons of pyrazoline in $\mathrm{H}_{\mathrm{A}}, \mathrm{H}_{\mathrm{B}}, \mathrm{H}_{\mathrm{X}}$ pattern. The signals for aromatic protons were observed in the region $\delta$ 7.71-8.08. The IR spectra of compound 3c showed the appearance of $\mathrm{C}=\mathrm{O}$ band at $1658 \mathrm{~cm}^{-1}$ and the other bands at 3095 and $1582 \mathrm{~cm}^{-1}$ corresponds to the $\mathrm{C}-\mathrm{H}$ and $\mathrm{C}=\mathrm{N}$ respectively. The mass spectrum of compound 3c showed molecular ion peak at $\mathrm{M} / \mathrm{z}=405.83(\mathrm{M}+)$, which is in agreement with the molecular formula $\mathrm{C}_{22} \mathrm{H}_{16} \mathrm{~N}_{3} \mathrm{O}_{3} \mathrm{Cl}$. Mass spectrum of pyrazolines was in good agreement with their suggested structure.

\subsection{Antioxidant activity}

The evaluation of antioxidant activity results (figure-1,2,3) revealed that most of the tested compounds exhibited moderate to weak antioxidant activity (in all the three methods) when compared with the positive control ascorbic acid. Among them, compounds possessing electron withdrawing groups like nitro, chloro, bromo on the phenyl ring influences the antioxidant activity. The compounds $\mathbf{3 e}, \mathbf{3 f}, \mathbf{3 g}$ showed moderate activity, when compared to the other tested compounds. The comparative result of the antioxidant activity indicated that compounds with bromo substituents are showed moderate activity than other derivatives.

\section{CONCLUSION}

A series of pyrazolines encompassing benzhydrazide derivatives were synthesized and evaluated for InVitro antioxidant activity. Results of the present study showed that, the tested pyrazolines derivatives exhibited moderate to weak activity in all the three methods, when compared to standard drug ascorbic acid. None of the tested compounds was found to be potent in comparison to standard. The study further requires structural modifications of these compounds, to make them valid lead compounds, which would possess better activity and may be quite useful for the pharmaceutical industries.

\section{Acknowledgement}

The authors are thankful to authorities of Nitte-Deemed to be University, Mangalore for providing financial support (Grant No: NUFR1/2016/18-04) and also providing all the necessary facilities. The authors also thankful to Vellore Institute of technology, Vellore, for providing NMR and Mass spectral data.

\section{References}

1. Sahu SK, Banerjee M, Samantray A, Behera C, Azam MA. Synthesis, analgesic, anti-inflammatory and antimicrobial activities of some novel pyrazoline derivatives. Trop. J. Pharm. Res. 2008; 7(2): 961-68.Crossref

2. Karabasanagouda T, Adhikari AV, Girisha M. Synthesis of some new pyrazolines and isoxazoles carrying 4methylthiophenyl moiety as potential analgesic and anti-inflammatory agents. Ind. J. Chem. 2009; 48B (3): 43037. Crossref 
3. Kumar B, Pathak V, Rani S, Kant R, Tewari IC. Synthesis and anti-microbacterial activity of some bromo-benzothiazolo pyrazolines. Int. J. Microbiol. Res. 2009; 1(2): 20-22.Crossref

4. Mbarki S, Dguigui K, Hallaoui ME. Construction of 3D-QSAR models to predict anti- amoebic activities of pyrazoline and dioxazoles derivatives. J. Mater. Environ. Sci. 2011; 2(1): 61-70.Crossref

5. Manna F, Chimenti F, Bolasco A, Cenicola ML, D'Amico M, Parrillo C. Anti-inflammatory, analgesic and antipyretic Nacetyl- $\Delta 2$-pyrazolines and dihydrothieno coumarines. Eur. J. Med. Chem. 1992; 27(6): 633-39.

6. Bilgin AA, Palaska E, Sunal R. Studies on the synthesis and antidepressant activity of some 1-thiocarbamoyl-3, 5diphenyl-2-pyrazolines. Arzneim-Forsch. Drug. Res. 1993; 43: 1041-404.Crossref

7. Xiang Wu, Prapon Wilairat, Mei-Lin Go. Antimalarial activity of ferrocenyl chalcones. Bio-org. Med. Chem. Lett. 2002; 12(17): 2299-302.CrossRef

8. Todigoppula N, Tanvir Khaliq, Shweta, Nishi, Neena Goyal, Suman Gupta. Synthesis of chromino chalcone and evaluation of their in vitro antileishmanial activity. Bio-org. Med. Chem. 2005; 13: 6543-50. CrossRef

9. Jen-Hao Cheng, Chi-Feng Hung, Shyh-Chyun Yang, Jih-Pyang Wang, Shen-Jeu Won, Chun-Nan Lin. Synthesis and cytotoxic, anti-inflammatory, and anti-oxidant activities of $2^{\prime}, 5^{\prime}$-dialkoxyl chalcones as cancer chemopreventive agents. Bio-org. Med. Chem. 2008; 16(15): 7270-76.CrossRef

10. Yuh-Meei Lin, Yasheen Zhou, Michael T. Flavin, Li-Ming Zhou, Weiguo Nie, Fa-Ching Chen. Chalcones and flavonoids as anti-tuberculosis agents. Bio-org. Med. Chem. 2002; 10: 2795-802.CrossRef

11. Nowakowska, Z. A review of anti-infective and anti-inflammatory chalcones. Eur. J. Med Chem. 2007; 42: $125-37$. CrossRef

12. Avila HP, Smania EFA, Monache FD, Smania A. Structure-activity relationship of antibacterial chalcones. Bio-org. Med. Chem. 2008; 16: 9790-94.CrossRef

13. Revanasiddappa BC, Subrahmanyam EVS, Lakshmi TN. Synthesis and biological evaluation of pyrazolines. Ind. J. Pharm. Edu. Res. 2011; 45: 164-67. CrossRef

14. Satyanarayana D, Revanasiddappa BC, Neema KV. Synthesis and biological evaluation of some novel pyrazolines. Ind. J. Het. Chem. 2013; 22: 353-56.

15. Revanasiddappa BC, Jisha MS, Varghese SS, Kalsi J, Jose N. Synthesis and biological evaluation of novel 1, 3, 5trisubstituted pyrazolines. Ind. J. Het. Chem. 2014; 24: 51-54.CrossRef

16. Revanasiddappa BC, Vijay Kumar M, Nayak P, Ajmal Roshan Ali, Jisha MS. Synthesis, antibacterial and antifungal evaluation of novel pyrazoline derivatives. Res. J. Pharm. Tech. 2017; 10: 1481-84.CrossRef

17. Gulcin I, Oktay M, Vioglu IKO, Ali A. Determination of antioxidant activity of lichen Cetrariaislandica (L) Ach. J. Ethanopharmacol. 2002; 79: 325-29.CrossRef

18. Jamuna S, Paulsamy S, Karthika K. Screening of In-vitro antioxidant activity of methanolic leaf and root extracts of HypochaerisradicataL. (Asteraceae). J. Applied. Pharm. Sci. 2012; 02 (07): 149-54.CrossRef

19. Mondal SK, Chakraborty G, Gupta M, Mazumder UK. In-vitro antioxidant activity of Dispyros malabarica Kostal bark. Ind. J. Exp. Biol. 2004; 44: 39-44.CrossRef

B.C. Revanasiddappa*, M.Vijay Kumar, Hemanth Kumar • Synthesis and Antioxidant Activity of Novel Pyrazoline Derivatives. Hygeia.J.D.Med 2018; 10(1):43-49. Available from http://www.hygeiajournal.com, DOI: 10.15254/H.J.D.Med.10.2018.177.

This is an Open Access article distributed in accordance with the Creative Commons Attribution Non Commercial (CC BY-NC 3.0) license, which permits others to share ,distribute, remix, transform, build upon this work non-commercially, and license their derivative works on different terms, provided the original work is properly cited and the use is non-commercial 